\title{
Tunus'ta Otoriter Yönetim ve İslamcı Hareketin Doğuşu: Burgiba Dönemi Üzerine Bir Değerlendirme (1956-1987)
}

\section{H. Rumeysa Dursun*}

$\ddot{0} \mathbf{z}$

$\mathrm{Bu}$ çalışma bağımsızlığın ardından Tunus'ta bir tek adam rejimi kuran Habib Burgiba dönemindeki gelişmeler üzerinden İslamcı hareketin doğuşunu incelemektedir. Tunus için ilerleme ve kalkınmanın ancak Batı'ya özgü yöntem ve değerleri takip etmekle mümkün olduğuna inanan Burgiba, ülkenin yüzyıllara dayanan Arap-Müslüman kültürü ile olan bağlarını tamamen koparmaya dönük adımlar atmıştır. Bu süreçte, devletin din üzerinde mutlak bir kontrol sağlaması amacıyla laiklik otoriter bir anlayışla yeniden yorumlanmıştır. Bununla birlikte, Burgiba tarafından halka tepeden dayatılan radikal sekülerleşme reformları ekonomik sorunlardan bunalan toplumda kabul görmemiştir. İslami duyarlılıklarla harekete geçen muhalif aktörler Burgiba döneminin sona ermesinde etkili olan toplumsal ve siyasal bir hareketin oluşmasında kilit rol oynamıştır. Bu bağlamda, çalışmada Tunus'ta İslami hareketin doğuşu ve siyasallaşma sürecinde Burgiba'nın hayata geçirdiği radikal reformların ve ekonomik krizin etkileri incelenecektir.

Anahtar Kelimeler: Tunus, İslami Hareket, Habib Burgiba, Sekülerleşme, Otoriter Laiklik.

* Dr., hr-montreal@hotmail.com 


\title{
Authoritarian Rule and The Origins of The Islamist Movement in Tunisia: An Assessment of The Bourgiba Period (1956-1987)
}

\author{
H. Rumeysa Dursun*
}

\begin{abstract}
This study examines the origins of the Islamic movement through the developments in the period of Habib Bourguiba, which established a one man regime in Tunisia after independence. Bourguiba, who believes that progress and development for Tunisia is possible only by following Western methods and values, has taken steps to completely tie the country to its ArabMuslim culture, which dates back to centuries. In this process, secularism has been reinterpreted in an authoritarian sense in order to give the state absolute control over religion. Nevertheless, the radical secularization reforms imposed on the public by Bourguiba have not been accepted in the ensuing society due to economic problems. The opposing actors who acted with Islamic sensitivities played a key role in the formation of a social and political movement that was effective at the end of the Bourguiba period. In this context, the study will examine the effects of the radical reforms and the economic crisis of Bourguiba period on the birth and the politicization of the Islamic movement in Tunisia.
\end{abstract}

Keywords: Tunisia, Islamist Movement, Habib Bourguiba, Secularization, Authoritarian Secularism

* Dr., hr-montreal@hotmail.com 


\section{Giriş}

Fransız protektora yönetiminin 1956 ' da sona ermesiyle birlikte bağımsızlığını elde eden Tunus'ta Habib Burgiba bağımsızlık hareketinin tartışmasız lideri olarak devletin başına geçmiş ve 1987'de bir saray darbesiyle görevine son verilene kadar bir tek adam yönetimi ortaya koymuştur. Yaklaşık yetmiş beş yıl devam eden Fransız protektora yönetimi deneyiminin ardından Tunus'un bağımsızlığını kazanmasında etkili olan milliyetçi hareket siyasi aktivizmin yerine toplumsal dönüşümü öncelik olarak belirlemiştir. Devlet ve Burgiban'nın Yeni Düstur Partisi adeta iç içe geçmiş ve "modern idari bir diktatörlük" ortaya çıkmıştır. ${ }^{1} \mathrm{Bu}$ toplumsal dönüşüm sürecinde ise, devletin din ile ilişkilerini yeniden düzenlemeye giriştiğini ve dini yaşantı üzerinde tam kontrolünü sağlamaya dönük adımlar attığını söylemek mümkündür. Bu bağlamda Burgiba'nın sekülerleşme reformları din ile devleti birbirinden ayırmayı değil, bunun aksine dinin devlet eliyle reforme edilmesini ve yeniden yorumlanmasını amaçlamaktadır.

Protektora yönetiminin sona ermesinin ardından İslam'ın ulusal birliğin sağlanması açısından taşıdığı önemi çok iyi bilen Burgiba dini unsurları tam anlamıyla denetim altına alarak modernist bir anlayışla yeniden yapılandırmayı hedeflemiştir. Böylelikle, bu süreçte uygulanan politikalar milliyetçi hareketin lideri Burgiba ve diğer Batı eğitimli seküler seçkinlerin İslam'ın kurumsal ve toplumsal işlevlerini reforme etme çabalarının bir yansıması olarak değerlendirilebilir. Laikliğin topluma baskı aracı olarak kullanıldığ1 bu dönemde, dini kurumlar yeniden şekillendirilmiştir. Modernleşme, ilerlerme ve kalkınma gibi idealleri gerçekleştirme gerekçesiyle İslam dini Tunus'ta siyasi ve toplumsal olarak etkisiz haline getirilmek istenmiştir. Çoğunluğu Müslüman olan bir topluma zorla kabul ettirilmek istenen bu siyasi proje, dini grupların siyasetten dışlanmasına ve muhalif bir İslami hareketin oluşmasına zemin hazırlamıştır. Bu bağlamda, makalede öncelikle Burgiba döneminde din-devlet ilişkilerinin şekillendiren sekülerleşme reformları incelenecektir. İkinci olarak, İslamcı haraketin siyasallaşmasında bir dönüm noktası olan ekonomik bunalıma giden süreç değerlendirilecektir. Daha sonra, İslamcı hareketin gelişmesi karşısında Burgiba rejiminin tepkisi ele alınacaktır. Sonuç olarak makale, Tunus'ta Burgiba döneminde hayata geçi-

Michel Camau, Tunisie au present: une modernite au-dessus de tout soupçon? Paris, Editions du CNRS, 1987. s. 31. 
rilen radikal laiklik uygulamaları ve ekonomik krizin İslamcı hareketin ortaya çıkmasında ve siyasallaşmasında büyük rol oynadığını savunmaktadır.

\section{Din ve Devlet İlişkilerini Şekillendiren Reformlar}

Protektora yönetiminin sona ermesinin ardından kurulan Tunus Devleti Habib Burgiba'nın büyük ölçüde tercihleri ve vizyonu doğrultusunda şekillenmiştir. Bağımsızlık sonrasında halkın rejime bağlılığının oldukça güçlü olduğu bir dönemde, 1956 yılı ilkbaharı ve yazında, Burgiba toplumsal ve siyasi alanı dönüştüren köklü reformlara imza attı. Kitleler üzerindeki etkisinin farkında olan Burgiba İslam'ın yeni kurulan Tunus Devleti'ndeki işlevini ve rolünü belirleyecek kararlar almıştır. Burgiba bu reformları gerçekleştirirken, İslam'ı yeniden yorumlama ve toplumu eğitme hakkını kendinde görmüştür. Bu bağlamda Burgiba aslında zihinsel bir dönüşüm gerçekleştirmek ve geçmişle olan bağları koparmak istemiştir. ${ }^{2}$ Michaud'ya göre, "Tunus'un modernleşme konusundaki yaklaşımı, "tutumların dönüştürülmesi”, "yeni değerler ölçüsü” oluşturulması ve "devrimci bir ruh" yaratılması inancıyla "psikolojik bir devrim" yapılması yönünde bir tercihi ortaya koymaktadır. ${ }^{3}$ Burgiba'nın reformları aslında modern ve seküler değerlere göre Tunus'u dönüştürerek ideal bir modern toplum inşa etme projesidir. ${ }^{4}$ Tunus'un modernleşme süreci boyunca Burgiba İslam dininin değerlerini toplumun önünde eleştirmekten geri durmamıştır. Öyle ki, protektora yönetiminin bile açıkça eleştiremediği dini konularda Burgiba büyük bir rahatlıkla kapsamlı bir dönüşüm gerçekleştirmiştir. ${ }^{5}$ Burgiba'nın dini unsurlar1 yeniden yorumlama konusunda bu kadar rahat davranmas1, kendisini İslam'ın temsilcisi olarak görmesi ve topluma bu şekilde kabul

Habib Boulares, Islam: The Fear and the Hope, London, Zed Books, 1990, s. 109.

3 Charles A. Michaud, Tunisia: The Politics of Modernization, New York, F. A. Preager,1964, s. 140.

4 Fred Halliday, "Tunisia's Uncertain Future" Middle East Report, 163, s. North Africa Faces the 1990's, 1990, s. 27.

5 Gannuşi, Burgiba'nın Tunus'ta hayata geçirdiği devrimlerin Türkiye'de benimsenen Kemalist uygulamalardan çok daha radikal nitelikte olduğunu vurgulamaktadır. Bkz: Raşid Gannuşi, "Secularism in the Arab Maghreb", Islam and Secularism in the Middle East Azzam Tamimi ve John Esposito (Ed.), New York, NYU Press, 2000, s. 105. Yine Gannuşi'ye göre, Burgiba Tunus'ta Arap-Müslüman kimliğinin etkisini zayıflatmak için Fransız yaşam biçimini dayatmıştır. Bkz: Anne Wolf, "An Islamist 'renaissance'? Religion and politics in post-revolutionary Tunisia", The Journal of North African Studies, Cilt 18, No 4, 2013, s. 561. 
ettirmesi ile açıklanabilir. ${ }^{6}$ Derek Hopwood, Burgiba'nın toplumu dönüştürme anlayışını şu şekilde ifade etmektedir:

Lider Burgiba açısından tüm Tunus ders verilen bir sınıf haline geldi. Atatürk örneğini takip ederek Burgiba halkını yeni yöntemler ve zihinsel tutumlar konusunda eğitmek istedi. Bu şekilde, politikalarını güçlendirmek ve ulusu sürekli olarak radyo ve televizyonu kullanarak eğitmek, yaşamın tüm boyutlarını kapsayacak şekilde reformlarını gerçekleştirmek istedi (...) Müslüman bir ülkede reformlar gerçekleştirmek isteyen birisi açısından dini alan bir mayın tarlası gibidir. Burgiba ise, Tunuslular'ın yaşantısında dinin değerinin farkındaydı. Yine de, dinin reformlara engel olmasını ya da tutumları sertleştirmesini istemiyordu (...) Burgiba fikirlerini desteklemek için Kuran'dan alıntılar yaptı. Burgiba'nın bunları kullanması, bir Müslümanın zihninde önceden yer eden bu alıntıların yeni fikirlerin kabul görmesini sağlamaktadır.?

Burgiba'nın Tunuslu Müslüman çoğunluğun tepkisini çekmemek ve gerçekleştirdiği toplumsal reformların kabul görmesini sağlamak için dini açıdan uygunluğunu açıklama ihtiyacı hissettiği anlaşılmaktadır. Tunus'ta tüm dini yapının devlet tarafından kontrol edilmesini sağlayan reformlar eğitim, hukuk ve toprak sistemini ilgilendirmektedir. Burgiba açısından Tunus'un modernleşmesi İslami kurumların radikal bir şekilde dönüştürülmesi anlamına gelmektedir. Seküler bir reformcu olan Kemal Atatürk'ten farklı olarak Burgiba kendini İslam'ın modernist bir yorumcusu olarak Tunus halkına sunmuştur. ${ }^{8}$

Burgiba'nın reform anlamında attığı ilk adım geleneksel Habu Konseyi'nin kaldırılması olmuştur. Tunus'ta vakıf topraklarının büyük çoğunluğu dini otoritelerin kontrolü altında bulunuyordu ve devlet bunların yönetimini reforme etme konusunda kararlıyd. Burgiba ve partisi özel vakıf topraklarını modernleşme ve ekonomik gelişme önünde bir engel olarak nitelendirmiştir. Yaklaşık yüz elli bin hektarlık vakıf topraklarının idaresini sağlayan bu kurum aynı zamanda cami, Kuran okulları ve diğer dini hayır kurumla-

6 Mohammed Sofi, "Modernization and Secularization in the Post-Independant Tunisia: An Analysis of Burguiba's reforms". Hamdard Islamicus. April-June, No 2. 2015, s. 14.

7 Derek Hopwood, Habib Bourguiba of Tunisia: The Tragedy of Longevity, Houndmills, Macmillan Press, 1992, s. 83-84.

8 Marion Boulby, "The Islamic Challenge: Tunisia since Independence", Third World Quarterly, Cilt 10, No 2, 1988, s. 592. 
rının finanse edilmesini sağlamaktaydı. Bununla birlikte Habu Konseyi, 1898 'den itibaren Avrupalı sömürgecilere yılda yaklaş1k 2,000 hektar toprak satan protektora yetkilileri ile işbirliği yaptığ 1 için itibarı zedelenen bir kurum haline gelmiştir. Bağımsızlığın hemen ardından 31 Mayıs 1956'da gerçekleştirilen reformun ardından yeni hükümet kendi otoritesini güçlendiren önemli bir adım atarak bu konseyi kaldırma kararı almıştır. Bu reform, devletin dini faaliyetler üzerinde tam bir denetim sağlamasında etkili olmuştur. ${ }^{9}$ Toprak reformu, Burgiba yönetiminin dini faaliyetlerin finansmanı ve idaresi üzerinde devletin kendi denetimini kurarak dini amaçlarla kullanılan toprakların kendi politikaları doğrultusunda kullanmasını sağlamıştır.

Burgiba'nın liderlik ettiği Yeni Düstur Partisi hükümeti, Hanefi ve Maliki dini mahkemeleri ve protektora yönetimi tarafından oluşturulan Fransız mahkemeleri kaldırmıştır. Dini mahkemelerin kaldırılmasıyla birlikte, şeriat tarafından izin verilen birçok uygulamanın yasa dışı hale gelmesine neden olan Medeni Kanun kabul edilmiştir. 13 Ağustos 1956'da kabul edilen bu kanun, Tunus'un toplumsal yapıssını temelden değiştirmeyi hedeflemiş ve çok eşliliği yasaklamıştır. ${ }^{10}$ Evlilik için belli bir minimum yaş belirleyen Kanun aynı zamanda küçük kızların satılması geleneğini yasaklamıştır. Böylelikle, evliliğin iki aile arasındaki bir ilişkiyi değil, iki birey arasındaki ilişkiyi ifade ettiğine dayanan modern anlayış öne çıkarılmıştır. Buna ek olarak, boşanma konusunda yeni prosedürler getirilmiştir. ${ }^{11}$ Tüm bu yenilikler İslam hukukundan önemli bir kopmayı ifade etmektedir. Kurumsal olarak dinin yetki alanlarının sınırlandırılması yeni rejim tarafindan modernleşmenin bir ön koşulu olarak değerlendirilmiştir. Burgiba'ya göre; "modern dünyanın bir parçası olarak yaşamak" ve "gerçekle yüzleşebilmek için diğer kültürlere, özellikle Batı kültürüne pencereleri açmak" için geleceği inşa etmek için gerekli araçları geliştirmek gereklidir. ${ }^{12}$ Görüldüğü gibi, Burgiba'nın İslami kurumları reform anlayışının temelinde Batı dün-

9 Clement H. Moore, Tunisia Since Independance: Dynamics of One-party Government. Berkeley, University of California Press, 1965, s. 50

10 Bruce Maddy-Weitzman, "The Islamic challenge in North Africa", B. Maddy-Weitzman ve E. Inbar (Ed.). Religious radicalism in the greater Middle East, London, Frank Cass, 1997, s. 177.

$11 \quad$ Ibid, s. 51.

12 Driss Abbassi, "La conception de l'histoire selon Bourguiba", Habib Bourguiba et l'établissement de l'Etat national 1957-1987: approches scientifiques du bourguibisme, Zaghouan, Publications F.T.R.S.I., 2000, s. 22. 
yası ile yakınlaşma ideali ve modern devletleri taklit etme isteği bulunmaktadir.

Burgiba'nın gerçekleştirdiği reformlar yalnızca kanunları değil aynı zamanda kadınların geleneksel kıyafetlerini de hedef almıştır. Burgiba'nın bakış açısına göre, Müslüman kadınların geleneksel kıyafetleri ve örtüleri, onların modern bir toplumda aktif bir şekilde yer almasına engel olmakta ve onları küçük düşürmektedir. Aynı zamanda başörtüsünü "iğrenç paçavra" olarak aşağılayan Burgiba başörtülü kadınları da rencide edici bir tutum sergilediğini söylemek mümkündür. ${ }^{13}$ Esasen, Burgiba'ya göre İslam'ın kadınlara başlarını örtmeyi zorunlu kılmamıştır ve başını Müslüman kadınlar İslam'a aykırı bir tutum içinde bulunmamaktadır. ${ }^{14}$ Geleneksel İslami örtünün aşağılanması, Tunus'ta tek parti hükümetinin dini kurumsal olarak kontrol etmenin ötesinde toplumun yaşayışına müdahale etme hakkını kendinde gördüğünü ve psikolojik bir baskı uyguladığını ortaya koymaktadır.

Yeni Düstur hükümeti tarafından hayata geçirilen bir diğer önemli reform ise eğitim sisteminin merkezileştirilmesidir. Dini eğitim kurumlarının milli eğitime bağlanması yönüne 1956 yılında alınan bir karar bu yaklaşımı sergilemektedir. Burgiba modern bir ulus devlette geleneksel eğitim sisteminin sürdürülmesinin uygun olmadığını savunmuştur. Eğitim sisteminin birleştirilmesinin bir diğer önemli sonucu ise Nisan 1956'da Zeytune Üniversitesi'nin milli eğitim sistemi içine dahil edilmesi ve Medrese-Üniversite'nin rektörünün milli eğitim bakanına karşı sorumlu hale getirilmesidir. Milli Eğitim Bakanı olarak atanan ve eğitim alanındaki reformların mimarı olan Mahmut Mesadi bu dönüşümün ilerleme ve medenileşme için yapı1dığını ve geleneksel dini eğitim sisteminin ise bunun önünde direnmemesi gerektiğini belirtmiştir. ${ }^{15} 1958$ yılında ise, Zeytune Medresesi'nin müfredatı tamamen değiştirilmiş yeni bir müfredat oluşturulmuş ve iki yıl sonra Tunus Üniversitesi'nin bünyesinde bir ilahiyat fakültesi olarak devletin kontrolü altına alınmıştır. ${ }^{16}$

Eğitim sisteminin reforme edilmesinin ülkenin dönüşümünde çok önemli etkileri bulunmaktadır. Geleneksel eğitim anlayışının bir kenara bırakılarak

13 Michaud, s. 148.

14 Sofi, s. 20.

15 Moore, s. 54.

16 Kenneth J. Perkins, A History of Modern Tunisia, Cambridge, Cambridge University Press, 2014, s. 146. 
modern bir eğitim müfredatının benimsenmesi Tunus'un batılılaşma yolunda devam etmesi anlamına gelmektedir. İlkokul seviyesinde Arapça ve Fransızca eğitim dili olarak kullanılmakla beraber, ortaokul ve yükseköğrenimde Fransızca temel eğitim dili olarak seçilmiştir. Ortaokulda derslerin sadece üçte birinin Arapça olarak verildiği dikkate alındığında, modern bilimsel bilgiye ulaşmanın tek yolunun Fransızca'yı çok iyi bilmekten geçtiği anlaşılmaktadır. ${ }^{17} \mathrm{Bu}$ durum, Tunuslu çocukların ve gençlerin eğitiminin, Fransız eğitimciler ve Fransız eğitim sisteminden gelen Tunuslu eğitimcilere emanet edilmesi anlamına gelmektedir. Geleneksel eğitim veren Zeytune Üniversitesi'nde eğitim almış bir eğitimcinin bu sistemde etkinlik göstermesi mümkün görünmemektedir. Reform sonrasında dini eğitim kurumlarının eski önemini kaybetmesi ulemanın siyasi ve toplumsal etki alanının daralmasına neden olmuştur.

Eğitim reformunun ardından ulemanın ve Zeytune Medresesi'nin etkinliğini zayıflatan Burgiba, İslam'ın beş temel şartından biri olan Ramazan orucunu hedef almıştır. Bu bağlamda, 5 Şubat 1960'da Ramazan ayının başlamasından üç hafta önce, Burgiba ekonomik geri kalmışlıkla mücadele edilmesinin önemini belirtmiş ve bunun için Ramazan orucunun terkedilmesi gerektiğini dile getirmiştir. ${ }^{18}$ Böylelikle, Burgiba İslam'ın temel ibadetlerinden birini açıkça eleştirmiş ve bu konuda yorum yapma yetkisini de kendinde görmüştür. Geri kalmışlığa karşı cihat edilmesi gerektiğini savunan Burgiba'ya göre, cihat oruçtan çok daha önemli bir ibadettir ve cihat durumunda bazı farzların terkedilmesinde herhangi bir sakınca bulunmamaktadır. ${ }^{19}$ Öte yandan, Burgiba oruçla ilgili konuşmasını yapmadan evvel, Tunus Müftüsü Abdülaziz Dicait ve Zeytune rektörü Tahir Bin Aşur'a konu ile ilgili danıştığını belirtmiş, halkın orucu bırakmasını istemediğini ama günlük faaliyetlerini olumsuz etkiliyorsa o zaman tatilde ya da emeklilikle orucun tutulabileceğini vurgulamıştır. ${ }^{20}$ Yine aynı şekilde, Burgiba Ramazan ayında çalışma saatlerinin değiştirilmeyeceğini belirtmiştir Burgiba'nın nezdinde dini kurallar günlük yaşamın koşullarına adapte edilmelidir. Eğer ibadetler insanı zorluyorsa onları terk etmek söz konusu olabilir.

\footnotetext{
17 Michaud, s. 153.

18 Yadh B. Achour, "Politique et Religion en Tunisie". Confluences Méditerranée, 33, 2000, s. 100.

19 Habib Bourguiba, Discours (1960-61). Vol. 8. Tunis, Secrétariat d'État à l'information, 1976, s. 258.

20 Rory McCarthy, "Re-thinking secularism in post-independence Tunisia" The Journal of North African Studies, Cilt 9, No 5, 2014, s. 737.
} 
Sonuç olarak, Tunus'ta bağımsızlığın ardından Burgiba'nın hayata geçirdiği kapsamlı reformlar hem ülkenin toplumsal dönüşümünde belirleyici bir rol oynamış, hem de dinin kurumsal otoritesini zayıflatmıştır. Siyasi alandaki dönüşüm böylece toplumsal alana doğru genişlemiş ve ülkenin köklü İslami kültürü yerine, ağırlıklı olarak Fransız etkisinin hissedildiği yeni Batılı bir kültür yerleştirilmek istenmiştir. Bunun en önemli göstergelerinden biri, Fransızca'nın yükseköğrenim dili olarak kalması ve toplumdaki seçkinlerin kullandığı dil olarak tercih etmesidir. Devletin resmi dili olan Arapça'nın yanında Fransızca'nın da kullanılması bu büyük dönüşümü ifade etmektedir. Bu tabloya bakıldığında, aslında Tunus'un siyasi olarak bağımsızlığını elde etmiş olsa da, kültürel ve toplumsal olarak halen Fransa'nın etki alanından çıkamadığını söylemek mümkündür. Bu bağlamda, Tunus'ta hükümetin kendi istediği yönde politikaları uygulamak ve toplumun buna muhalefet etmesine engel olmak için İslam'1 yeniden yorumladığı ve devletin kontrolü altına aldığı görülmektedir.

\section{Yeni Düstur Partisi’nin Dönüşümü ve Ekonomik Sorunlar (1962-1980)}

Burgiba göreve geldiğinde uygulanacak ekonomik politikalar konusunda tam olarak net bir fikre sahip değildi. Başlangıçta uygulanan liberal politikalar beklenen yatırımların gelmemesi sonucunda 1961 yılında açıkça sosyalist bir ekonomi politikasına geçmeye yöneltmiş̧ir. Sosyalist ekonomi politikaları ise Ekonomi ve Finans Bakanı Ahmet Bin Salah öncülügünde hayata geçirilmiştir. İdeolojik olarak sosyalizme yönelen Yeni Düstur Partisi, 1964 'teki parti kongresinde ismini Sosyalist Düstur Partisi (Parti Socialiste Destourien - PSD) olarak değiştirmiştir. Beklenen büyümenin gerçekleşmemesi üzerine 1969 yılında sosyalist ekonomi politikaları terkedilmiş ve yerine yeniden liberal politikalar tercih edilmiştir. 1960 ve 1967 yılları arasında y1llık büyüme oranı yüzde 3,3'te kalmış, endüstriyel büyüme oranı yüksek olsa da, tarımda yaşanan problemlerin çözülmesi için yeterli olamamıştır. ${ }^{21} 1967$ yılı sonu itibariyle Tunus'un dış borçları milli gelirin yüzde 45'ine tekabül eden 225 milyon dinara ulaşmıştır. ${ }^{22}$ Bin Salah, uyguladığ 1 ekonomi politikalarının başarısız olması üzerine 1969 yılında Burgiba ta-

21 Lisa Anderson, The state and social transformation in Tunisia and Libya: 1830-1980. Princeton, Princeton University Press, 1987, s. 238.

22 Jacob Abadi, Tunisia since the Arab Conquest: The Saga of a Westernized Muslim State. Cornwall, Ithaca Press, 2013, s. 484. 
rafından görevden alınmıştır. 1970 yılından itibaren uygulanmaya başlanan liberal politikalar ise, siyasal alanda muhalif seslerin ortaya çıkmasında etkili olmuştur. Toplumsal açıdan değerlendirildiğinde, sosyalist ideolojinin terkedilmesi sonrasında oluşan ideolojik boşluk İslami eğilimli aktörlerin kendini göstermesi için uygun bir ortam oluşturmuştur Esasen bu aktörler Tunus toplumunun içinde bulunduğu ekonomik sıkıntılar, gelir adaletsizliği ve fakirlikten duyulan rahatsılıl̆ğn siyasal alanda seslendirilmesinde etkili olmuştur. ${ }^{23}$ Zeytune Medresesi öğrencileri tarafından kurulan Kuran'1 Koruma Derneği (Association pour la Sauvegard du Coran) ise, İslami kimliğin yeniden Tunus toplumunu kuşatması gerektiğini savunarak bu dönemde öne çıkmıştır. ${ }^{24}$ Hükümetin Batılılaşma ve sekülerleşme politikalarını eleştiren bu grup, geleneksel İslami değerlerin topluma yön vermesini istemektedir. Burgiba ve O'na yakın siyasi liderlerin şaşırtıcı bir şekilde bu derneğin faaliyetlerini kısıtlayıcı bir girişimde bulunmadığı görülmektedir. Esasen, ekonomi politikalarının başarısız olduğu ve yönetimin yoğun bir şekilde eleştirildiği bir dönemde, hükümetin rejime muhalif olan çevrelerin etkisini zayıflatmak için bu muhafazakâr derneği bir kalkan olarak değerlendirdiği düşünülebilir. ${ }^{25}$

Diğer taraftan, Bin Salah'ın görevden alınmasına neden olan ekonomik sıkıntıları gidermesi için Burgiba Hedi Nuira'yı 1970'te başbakan olarak atamıştır. Nuira hükümeti ekonominin istikrar kazanmasını sağlamış ve 1973-1977 yılları arasında ekonomi yılda yüzde 5,6 oranında büyümüştür. Yabancı yatırımcıları ülkeye çekmek için vergi muafiyeti gibi kolaylıklar sunulmuştur. ${ }^{26}$ Bununla birlikte, Nuira'nın 1973-75 yılları arasında uyguladığ 1 ilk beş yıllık programın yeni sektörlerin kıyı kesimdeki bölgelerde gelişmesi noktasında önemli bir ilerleme sağlamadığı görülmektedir. Tekstil ve giyim alanında yapılan yatırımlar ise Avrupa Ekonomik Topluluğu'nun 1977 kendi iç pazarını korumaya yönelik uyguladığı yüksek tarifeler nedeniyle karlı bir pazardan mahrum kalmıştır. Bunun sonucunda ürünlerini satabilecek uygun bir pazar bulamadığı için birçok fabrika kapanmak zorunda kalmıştır. Bu bağlamda, Nuira'nın ilk beş yıllık programının ekonomide

23 Stephen King, Liberalization Against Democracy: The Local Politics of Economic Reform in Tunisia, Bloomington, Indiana University Press, 2003, s. 28-29.

24 Abadi, s. 485.

25 Perkins, s. 162-163.

26 Mohsen Toumi, La Tunisie de Bourguiba à Ben Ali, Paris, Presses Universitaires de France, 1989, s. 134. 
yapısal dönüşümlerin gerçekleşmesini sağlamadığı söylenebilir. Esasen, büyük yatırımlar yapma imkânı olan ya da yabancı girişimcilerle ortaklık kurabilen zengin küçük bir grubun refah seviyesi yükselmiş olsa da, milli gelirden maaşlara ayrılan miktarda ciddi bir düşüş yaşandığı gözlenmektedir. Zenginler ve fakirler arasındaki gelir uçurumunun iyice derinleşmesi ise düşük gelirlilerin tepkisini doğurmuştur. ${ }^{27} \mathrm{Bu}$ dönemde işçilerin taleplerini PSD ile müzakere etme pozisyonunda ise 1971 yılında Tunus Genel İşçi Sendikası (Union Générale des Travailleurs Tunisiens -UGTT)'nın genel sekreteri olan Habib Aşur bulunuyordu. 1973 y1lında hükümetin işçilerle müzakere için getirdiği ve iş bırakmayı yasaklayan sisteme rağmen sendika üyeleri seslerini hükümete duyurabilmek için greve gitmiştir. 1977'de uygulanmaya başlanan ikinci beş yıllık plan ise UGTT ve hükümet arasındaki anlaşmazlığın büyümesine neden olmuştur. İşçilerin greve son vermesi için Aşur'a baskı yapan hükümet, vaatlerini yerine getiremeyince grev devam etmiştir.

Ocak 1978'de hükümetin tavrından duyduğu rahatsılılı̆ı göstermek isteyen Habib Aşur partinin siyasi bürosundan ayrılmış ve bağımsızlığın ardından ilk defa UGTT 26 Ocak günü genel greve gitme kararı almıştır. "Kara Perşembe" olarak bilinen grev günü çıkan olayları bastırabilmek için hükümet olağanüstü hal ilan etmiş ve şiddet olayları tüm ülkeyi sarsmıştır. Birçok kişinin ölümü ve yaralanmasıyla sonuçlanan olaylardan sorumlu tutulan sendikacılar ve Aşur tutuklanmış ve hapis cezası almıştır. "Kara Perşembe", hükümetin kendisine yönelik muhalefeti bastırma konusundaki kararlılığını ve bu konuda ne kadar acımasız olabileceğini tüm Tunuslulara göstermiştir. Öte yandan, hükümetin işçi isyanlarını bastırırken uyguladığı orantısız güç ve şiddetin rejime muhalif olanların harekete geçmesinde itici bir etken olduğu gözlenmektedir. Bu olayların ardından Şubat 1979'da İran'da gerçekleşen İslam Devrimi ise ülkedeki gençleri derinden etkileyen bir olay olmuştur. İşçi ayaklanmasının şiddet yoluyla bastırılması İslami eğilimli aktörlerin işçilerle birlikte hareket etmeye başlamasında etkili olmuştur. ${ }^{28}$ Ocak ayında UGTT'nin başlattığı ayaklanma, muhafazakâr gençlerin siyaset sahnesine çıkmasında bir dönüm noktasına işaret etmektedir. Gannuşi, genel grev ile başlayan ve tüm ülkeyi saran eylemlere İslami eğilimli aktörlerin nasıl baktığını şu sözlerle ifade etmektedir:

\footnotetext{
27 Perkins, s. 165-168.
}

28 Abadi, s. 495. 
$\mathrm{Bu}$ şiddet olaylarında tarafsız kaldık ve bu olayların hiçbirine katılmadık. Sendikacılığın bize yabancı olduğunu şeklinde bir önyargımız olduğu için, sendika faaliyetinde bulunmadık. Zengin ve fakir arasındaki toplumsal çatışma Marksist bir formül ve bizim hayat anlayışımıza tekabül etmiyor. Daha sonra, İslam'ın bu çatışma ile ilgili bir yorumu olduğunu ve bizim Müslümanlar olarak buna kayıtsız kalamayacağımızı kavradık. Bu noktadan itibaren, toplumsal gerçeklikler konusunda farkındalık ve duyarlılık geliştirmeye başladık. İslamcılar sendika hareketlerine katılmaya başladı ve günümüzde bu hareketler içinde çok önemli bir güç olarak yer almaktadır. ${ }^{29}$

Gannuşi'nin değerlendirmeleri dikkate alındığında, işçi ayaklanmasının aslında hükümetin politikalarına tepki duyan muhafazakâr çevrelerin harekete geçmesi için itici bir güç oluşturduğunu ortaya koymaktadır. Ocak ayında yaşanan olayların ardından, muhafazakâr İslami hareketin ilk siyasi bildirisini yayınladığı görülmektedir. Gannuşi tarafından kaleme alınan ve "Demirperde Düşmeden Evvel" başlıklı bildiri, işçilerin meşru taleplerini desteklemekte ve Tunus'un bir iç savaşa sürüklenmesinden duyulan endişeyi ifade etmektedir. Bu bildirinin yayınlanması ile birlikte, Tunus'ta İslami hareketin siyasete daha aktif bir şekilde katılmaya başladığı gözlenmektedir. Esasen, başlangıçta rejimin İslam karşıtı politikalarına bir tepki olarak ortaya çıkan ve dini duyarlılığı ön planda tutan bu oluşum, Marksist sendikacıların sosyal adalet söylemleri ile yakınlık kurmuştur.

Böylelikle, muhafazakâr aktörler çok daha kapsamlı dini, toplumsal ve siyasi boyutları dikkate alarak otoriter rejime karşı mücadele etmeye başlamıştır. ${ }^{30}$ Her ne kadar İslami unsur hareketin kurulmasında temel bir rol oynamış olsa da, 1978 'deki sendika eylemleri hareketin toplumun tamamını ilgilendiren sorunlara duyarlılık göstermesinde ve bu sorunların çözümü için harekete geçmesinde bir dönüm noktası olmuştur. ${ }^{31}$ Ütopik İslami devlet ve İslami toplumsal adalet anlayışını bir kenara bırakan hareketin mensupları sendikalara katılmaya başlamış ve buralarda halkla doğrudan iletişim sağlamış ve toplumsal tabanını genişletmiştir. Bir anlamda 1978

29 Mohamed Hamdi, The Politicization of Islam: A Case Study of Tunisia. Boulder, Colo: Westview Press, 1998, s. 32.

30 Ibid.

31 François Burgat, L'Islamisme au Maghreb: la voix du sud. Paris, Karthala, 1988, s. 208209. 
işçi krizi, muhafazakâr hareketin istikametinin yeniden tanımlandığı ve halkla yakınlaştığı bir süreci ifade etmektedir.

\section{Tunus'ta İslami Hareketin Gelişmesi ve Burgiba Rejiminin Tepkisi}

Yukarıda incelenen işçi olaylarının yaşandığı dönem, Tunus'ta muhafazakâr hareketin siyasallaşma aşamasının başlangıcı olarak gösterilebilir. Burgiba'nın hayata geçirdiği seküler reformlara bir tepki olarak öncelikle Zeytune Cami'ndeki sohbet halkalarında bir araya gelen hareketin kurucuları, Tunus toplumunu sekülerleştirme çabalarından büyük rahatsızlık duyan bir kitleyi temsil etmektedir. ${ }^{32} \mathrm{Bu}$ sohbet halkalarının üyeleri özellikle camiler ve ortaokullarda organize olmaya başlamıştır. Kendilerini Jamaa al-Islamiyyah olarak isimlendiren grup 1969 yılında davet üzerine Kuran'1 Koruma Derneği'ne katılmayı kabul etmiştir. Bu dernek, Ahmet Bin Salah tarafindan hayata geçirilen sosyalist ekonomi politikasının başarısız olması sonrasında üniversite kampüslerinde solcu grupların güçlenmesine engel olmak isteyen hükümet tarafindan da desteklenmekteydi. ${ }^{33}$ Sosyalist ekonomi politikasının terkedilerek hızlı bir şekilde liberal bir programın benimsenmesi ekonomik sorunları çözmek yerine daha da derinleştirmiş, işsizlik artmış, y1llık ortalama gelir ise bir türlü iyileştirilememiştir. Ülkenin ekonomik olarak zor günler geçirdiği böyle bir dönemde İslami hassasiyetleri bulunan gençler sohbet halkalarında bir araya gelerek Burgiba'nın politikalarından duydukları rahatsızlığı paylaşma imkânı bulmuştur. 1972'de al Ma'rifa dergisini çıkarmaya başlayan hareket böylece daha toplumun daha geniş kitlelerine ulaşmayı hedeflemiştir. Gannuşi, Burgiba'nın İslam karşısındaki katı tutumunu şu sözlerle eleştirmektedir:

Burgiba, 1957'de başörtüsünü yasakladı ve kadınların başörtülerini kamusal hayattan çekti. Sonra 1981'de kadınların kamusal hayatta başörtüsü kullanmalarını yasaklayan kanunu çıardı. Kadınların başörtüsüyle üniversitelere, okullara girmesini engelledi. 1957'de çok eşliliği yasakladı. Bu yasalar bugün hâlâ yürürlükte. Burgiba, 1960’ta Ramazan'da oruç tutulmasını yasakladı ve bunun ülke ekonomisine zararlı olduğunu

Emad E. Shahin, Political Ascent: Political Movements in North Africa. United States of America, Westview Press, 1998, s. 67.

33 Micheal Willis, Politics and Power in The Maghreb: Algeria, Tunisia and Morocco from Independance to the Arab Spring. London: Hurst\&Co., 2012, s. 160. 
söyledi.1974'te Kuran'ın kendi kendisiyle çelişkili olduğunu iddia etti ve $\mathrm{Hz}$. Muhammed'in mucizeleri ile dalga geçti. ${ }^{34}$

1970'li yılların başından itibaren Zeytune Camii, rejimin politikalarını benimsemeyen ve ulusal dini kurumlar içinde yer almayı kabul etmeyen Salah el-Naifar, Ahmed Bin Melad, Abdel Kader Salama'nın da aralarında bulunduğu birçok dini liderin toplandığı bir yer olmuştur. Zeytune Medresesi'nin çok saygın bir din âlimi olan Şeyh Bin Melad özellikle ortaokul ve üniversitelerde İslami eğitim konusundaki eksiklikten duyduğu endişeyi paylaşmış ve aralarında Abdülfettah Moro, Raşid Gannuşi gibi isimlerin bulunduğu gençlerin bu konulara duyarlılık kazanmasını sağlamıştır. Daha sonraları Gannuşi ve Moro, Hamida al-Naifar ve Salah Eddin el-Jourshi'ye katılarak İslami Yöneliş Hareketi (MTI; Mouvement de Tendance Islamique)'nin kurcuları arasında yer almıştır. Tunus'un sahil kasabası olan el-Hamma'da 1941 yılında dindar bir ailede doğan Gannuşi ortaokulu Zeytune Medresesi'nde okumuştur. Burgiba rejiminin eğitim sistemini sekülerleştirme projesinin bir parçası olarak Zeytune'yi 1960'larda kapatılması üzerine yükseköğrenimi yapmak için Suriye'ye gitmek zorunda kalmıştır. ${ }^{35}$ Esasen Tunus'ta üniversite eğitimi almak için Fransızca bilmenin zorunlu olması nedeniyle, Gannuşi gibi Fransızca bilmeyenlerin kendi ülkelerinde yükseköğrenim görmesi mümkün değildi. Suriye'de aldığ1 eğitim süresince farklı İslami gruplarla tanışan Gannuşi’nin toplumdaki sorunlara dini ilkeler 1şığında çözüm üretilebileceği inanc1 güçlenmiştir. ${ }^{36}$ Gannuşi, yabanc1 bir dilin anadili Arapça olan bir topluma eğitim alanında dayatılmasından duyduğu rahatsızlığı ve nasıl zor bir durumda bırakıldıklarını şu sözlerle ifade etmektedir.

Ortaokul eğitimimi Tunus hükümeti tarafından kapatılmadan evvel Zeytune Medresesi'nde tamamladım. Bağımsızlığın ilk yıllarında Zeytune'de eğitim gören öğrencilerden biriyim. Kendi ülkemizde kendimizi birer yabancı gibi hissettiğimizi hatırlıyorum. Biz Müslüman ve Arap olarak yetiştirilirken, ülke bütünüyle Fransız kültürel kimliği ile iç içe geçmişti. Üniversite tamamen Batılılaştığı için bize eğitimimize devam etme kapıları kapanmıştı. Bu dönemde eğitimine Arapça devam etmek

\footnotetext{
Hamdi, s. 13.

Shahin, s. 67-68.

36 Azzam Tamimi, Rachid Ghannouchi: A democrat within Islamism, New York, Oxford University Press, 2001, s. 20.
} 
isteyenlerin Ortadoğu'ya gitmesi gerekiyordu. Ben, eğitimini Ortadoğu'da tamamlamaya karar verenlerden biriydim. ${ }^{37}$

Yine hareketin kurucuları arasında bulunan Abdülfettah Moro Tunuslu dindar bir ailede doğmuş ve temel İslami bilgilerini de ailesinde almıştır. Modern ve geleneksel eğitimin birlikte verildiği Sadıki Koleji'nde okumuş ve Tunus Üniversitesi'nde hukuk eğitimi almıştır. Zeytune ve diğer camilerde Kuran dersleri veren Moro, İslami hareket içindeki önemli isimlerden biridir. Hareketin bir diğer kurucusu olan Şeyh Hamida el-Naifer Tunus'ta dini kurumlarda oldukça etkin köklü bir aileden gelmektedir. Tunus İlahiyat Fakültesi'nde profesör olan el-Neifer, Gannuşi gibi eğitimine Suriye'de devam etmiştir. Gannuşi ile tanışmadan evvel Nasırizmden etkilenen el-Neifer daha sonra Arap milliyetçiliğinin Müslümanların içinde bulunduğu sorunların çözümü olmadığını anlamış ve İslami fikirlere yakınlaşmıştır. ${ }^{38}$ Görüldüğü gibi hareketin kurucuları Tunus'ta bağımsızlığın ardından oluşturulan sistem içinde kendilerini adeta bir yabancı olarak görmekte ve kendi ülkelerine yabancılaşmalarına neden olan soruna bir çözüm arayışı içinde bulunmaktadır. Eğitim gördükleri sırada Arap milliyetçiliğinden etkilenen bu genç aktivistler daha sonra İslami ilkelerin sorunlarına çözüm olacağına inanmışlardır.

1970-1978 yılları arasında kendi içine kapalı olan İslami hareket siyasi ve sendikalist faaliyetlere katılmamakta ve daha ziyade İslami değerleri savunan ahlaki misyonu ile öne çıkmaktayd1 ${ }^{39}$ Tunus'ta hükümetin karma bir ekonomi politikası uyguladığ 1970'lerde liberalleşme stratejisinin bir sonucu olarak özel sektör devletten daha fazla destek görmeye başlamıştır. Bu dönemde ekonomide belli bir büyüme sağlanmış olmakla birlikte 70'li yılların sonuna doğru ülke ciddi ekonomik sorunlarla yüzleşmek durumunda kalmıştır. Avrupa'nın Tunus ihracatını sınırlayan politikaları, tarım üretiminin gerilemesi ve uluslararası ihracat gelirlerinin düşmesi bu sıkıntılar arasında sıralanabilir. Ekonominin ilk etapta yaşadığ 1 canlanmanın bir sonucu olarak, köyden kente göç edenlerin sayısında ciddi bir artış yaşanmıştır. 1970'lerin sonlarına doğru ise, ekonomik büyümenin yavaşlaması sonucu köyden gelen işsizlere üniversiteden yeni mezun olanların eklenmesiyle işsizlik ciddi bir toplumsal ve ekonomik sorun haline gelmiştir.

\footnotetext{
Hamdi, s. 17.

Shahin, s. 69.

Abadi, s. 496.
} 
Fakir ve zengin arasındaki gelir adaletsizliğinin artması ise, toplumdaki dar gelirlilerin hükümetin politikalarından duyduğu hoşnutsuzluğun artmasına neden olmuştur. Tüm bu gelişmelerden en çok rahatsızlık duyan kesim ise işçiler ve gençlerdi. Bu dönemde İslami harekete gençlerin yönelmesinin bir nedeni de yaşanan işsizliğin olumsuz etkileridir. 1971-1972 yıllanı arasında üniversite öğrencileri arasında çıkan huzursuzluklardan dolay1 Tunus Üniversitesi aylarca kapalı kalmıştır. Bunlara ek olarak, 1970’lerin başından itibaren hükümet, fabrikaların ve üniversitelerin kendi camilerini açmalarına izin vermiştir. ${ }^{40}$ Arap-İslam kültürünün yeniden canlandırılarak toplumda ekonomik daralmanın yarattığ tepkinin büyümesine engel olunması, hükümetin böyle bir adım atmasındaki en önemli etken olarak yorumlanabilir. Böylelikle bu camilerde oluşan dini sohbet halkaları Tunus'ta İslami muhafazakâr hareketin işçiler ve üniversite öğrencilerinin katılımıyla güçlenmesini sağlamıştır. Görüldüğü gibi, yaşanan ekonomik sıkıntılar halkın hükümet politikalarına olan tepkisinin büyümesine neden olmuştur. Özellikle işçilerin ve gençlerin doğrudan etkilendiği fakirlik ve işsizlik, bu kesimlerin İslami harekete yakınlaşmasında etkili olan faktörler arasında gösterilebilir.

1978'de Tunus hükümetinin UGTT tarafindan organize edilen genel grevi bastırırken yaşanan şiddet olaylarının sonucunda gerçekleşen zihinsel dönüşüm Tunus'ta muhafazakâr hareketin tarihi açısından dönüm noktasını oluşturmaktadır. Bu tarihten itibaren kendi içine kapalı olan İslami anlayış bir kenara bırakılmış ve böylece hareket toplumun sorunlarıyla doğrudan ilgilenmeye başlamıştır. Buna ek olarak, 1979 yılında İran'da gerçekleşen İslam devrimi Tunus'ta da İslami hareket içinde büyük bir coşku yaşanmasına neden olmuştur. Al-Ma'rifa dergisinin 12 Şubat'ta çıkan sayısında Gannuşi İran İslam Devrimi'nden duyduğu memnuniyeti şu sözlerle ifade etmektedir; "Íslam için mücadele eden adalet ve özgürlüğü destekleyen herkesin Iran'da özgürlük ve adalet için savaşan din kardeşlerimizin güçlü, net, samimi ve sağlam bir şekilde arkasında durmasını istiyoruz". ${ }^{41} \mathrm{Bu}-$ nunla birlikte, dini dönüşümün toplumsal ve siyasi koşulların değişmesini sağlamadığını gören Gannuşi, daha farklı bir yaklaşım uygulamaya başlamıştır. Böylece, 1979'da Kuran'1 Koruma Derneği, içinde danışma konseyi (majlis al-shura) bulunan oldukça gelişmiş yapıya sahip İslam Derneği

$40 \quad$ Shahin, s. 76.

41 Hamdi, s. 33. 
(Jamaa al-Islamiyya-Islamic Association) 'ne dönüşmüştür. İran devrimi ve Müslüman ülkelerde oluşturduğu yankılar, Burgiba ve hükümet çevrelerinde endişe uyandırmış ve bunun üzerine hareketin yayın organı olan $a l-M a-$ rifa dergisi 1979 yılında yasaklanmıştır.

$\mathrm{Bu}$ tarihten sonra ise, hareketin gitgide daha aktif bir şekilde siyasi faaliyetlerde yer alması ve işçi sendikası olan UGTT ile daha yakın bir işbirliği içine girdiği gözlenmektedir. Nisan 1981'de Burgiba siyasal alanda liberalleşmeye gidilmesine karar vermesi üzerine İslami Derneği aynı yıl haziran ayında ismini İslami Yöneliş Hareketi (Harakat al-Ittijah al-Islami/Mouvement de la Tendance Islamique /MTI) olarak değiştirmiştir. ${ }^{42}$ Öte yandan sosyalist ekonomi politikalarının başarısız olması üzerine Burgiba, partisinin mensuplarının bundan böyle başka toplumsal ve siyasi oluşumlara karşı çıkmayacağı konusunda taahhütte bulunmuştur. ${ }^{43}$

Haziran 1981'de MTI siyasi bir parti olarak tanınmak için resmen hükümete başvurmuş ve basın açıklaması yaparak amaçlarını kamuoyu ile paylaşmıştır. Bu bağlamda, İslam'ın Tunus toplumundaki merkezi önemine dikkat çeken beş amaçtan bahsedilmektedir. İlk olarak, geleneksel İslam kültürünün temelinin oluşturan İslami kimliğin Tunus’ta yeniden canland1rılması ve Batı'nın doğrudan taklit edilmesine dayanan ilerleme anlayışının bırakılması gerektiği vurgulanmaktadır. İkinci olarak, İslami düşüncenin günümüz koşulları ve ihtiyaçları doğrultusunda yeniden temel ilkeleri çerçevesinde yorumlanması gerektiği belirtilmektedir. Üçüncü olarak, iç ve dış herhangi bir müdahale olmaksızın milletin iradesini yeniden hâkim olmalıdır. Dördüncü olarak, herkesin emeği ve ihtiyacı doğrultusunda hakkettiğini milli kaynaklarından almasını sağlayabilecek bir toplumsal adalet sisteminin yerleştirilmesi üzerinde durulmaktadır. Son olarak ise, İslam'ın ulusal, bölgesel ve uluslararası düzeyde siyasi ve kültürel yeniden canlandırılması ve her türlü psikolojik, ekonomik ve uluslararası zulümden korunmasının önemi ifade edilmektedir. Görüldüğü gibi, MTI'nin amaçları ekonomi, siyaset, toplumsal adalet ve kimlik politikası gibi alanları ilgilendirmektedir. Her ne kadar, İslami kimlik merkezi bir öneme sahip olsa da, hareket toplumun sorunlarını bir bütün olarak değerlendirmekte ve dini

42 Alaya Allani, The Islamists in Tunisia between confrontation and participation: 19802008. The Journal ofNorth African Studies, Cilt 14, No 2, 2009, s. 260.

43 John Esposito ve J. Voll, Makers of contemporary Islam, New York, Oxford University Press, 2001, s. 101. 
alan dışındaki sorunları da dikkate almaktadır. Basın önünde partinin tanıtımını yaptıktan sadece beş hafta sonra hareketin liderleri hapse atılmıştır. 18 Temmuz 1981'de otoriteler, aralarında Gannuşi ve Moro'nun da bulunduğu İslami harekete mensup birçok kişiyi tutuklamıştır. Gannuşi ve Moro on yıl hapse mahkûm edilmiş ve yalan haberler yaymakla suçlanmıştır. ${ }^{44}$

Burgiba rejiminin komünist bir siyasi partinin faaliyet göstermesine izin verdiği halde, muhafazakâr bir partinin faaliyet göstermesine izin vermemesi oldukça düşündürücüdür. Burgiba yönetimi tarafından illegal bir örgüt olduğu gerekçesiyle yasaklanan MTI aslında rejimin siyasi gücüne rakip olan muhafazakârları siyasetten uzak tutuma konusundaki kararlılığını ortaya koymaktadır. ${ }^{45}$ Sonraki yıllarda MTI basının saldırılarına muhatap olmuş ve üyelerinin büyük kısmı gözaltına alınmış ve hapse atılmıştır. Tüm bu baskılara karşın, MTI aktif bir şekilde faaliyet göstermeye devam etmiş ve örgütsel yapısını korumuştur. Gizli bir şekilde çıkarılan al-Risala ve al-Masar isimli dergiler hareketin aktif kalmasını sağlamıştır. Bununla birlikte, Ocak 1983'te hareketin 40 önemli liderinin daha tutuklanmas1 sonucunda birçok üye Fransa'ya kaçmış ve orada bir siyasi büro açarak hareketi buradan yönetmeye çalışmıştır. ${ }^{46}$ Hükümetin MTI ve onun altyapısına yönelik uyguladığı baskı, rejimin aslında demokratikleşme ve siyasal liberalizm konusundaki söyleminin hiç de samimi olmadığını gözler önüne sermektedir. Bu bağlamda, Tunus'ta muhafazakâr hareketin liderlerinin hapse atılması ve siyasete katılımının engellenmesi, demokrasinin çoğulcu bir yapı kazanmasına mani olduğunu söylemek mümkündür.

Diğer taraftan, 29 Aralık 1983 ve 4 Ocak 1984 arasında ülkenin en önemli şehirlerinde ekmeğin fiyatının beklenmedik bir şekilde artmasını protesto eden gösteriler düzenlenmiştir. Halkın yoğun tepkisiyle karşılaşan polis olayları kontrol altına almakta zorlanmış ve olağanüstü hal ilan edilmiştir. Bu şiddet olaylarında elli kişi hayatını kaybetmiş ve Burgiba ekmeğin fiyatının arttırılması kararından vazgeçmek zorunda kalmıştır. Sokak isyanlarına dönüşen ekmek krizi sonrasında, Burgiba ülkede sükunetin sağlanması ve yoksulluktan bunalan halk nezdinde zedelenen itibarının yeniden güçlendirilmesine önem verdiği görülmektedir. Bu dönemde başbakan Mohamed

\footnotetext{
44 Hamdi, s. 42-43.

45 John Esposito, ve J. Piscatori., "Democratization and Islam", The Middle East Journal, Cilt 45, No 3, 1991, s. 431.

46 Shahin, s. 88.
} 
Mzali, Burgiba'ya hapiste bulunan MTI üyelerinin serbest birakılmasın1 teklif etmiștir. Mzali ve MTI'nin genel sekreteri Abdülfettah Moro arasındaki görüşmelerin ardından Ağustos 1984'te hapiste bulunan hareketin liderleri serbest bırakılmıştır. ${ }^{47}$ Üyelerinin serbest bırakılması üzerine MTI 1984 yılın sonlarına doğru bir konferans düzenlemiş ve burada hareketin içyapısının geliştirilmesi yönünde kararlar alınmıştır. Gannuşi’nin yeniden MTI'nin lideri olarak seçildiği bu konferansta hareketin daha aktif bir şekilde sendikalarda, kültürel kuruluşlarda ve gençlik derneklerinde faaliyet göstermesine karar verilmiştir. MTI'nin yeniden yapılanma sürecinin ise üç aşamada gerçekleşmesi öngörülmüştür.

Böylece ilk olarak, hareketin ülke genelindeki merkezi ve yerel yapısının yeniden organize edilmesi gündeme gelmiştir. Yerel komitelerin neredeyse tamamı yenilenmiş ve başına hareketin önemli liderleri getirilmiştir. İkinci olarak, 6 Haziran 1985'te MTI'nin ikinci ulusal siyasi bürosunun açıldığı kamuoyuna duyurulmuştur. Dahası, iktidar partisinin ardından Tunus'taki en güçlü siyasi kuruluş olan UGTT'nin ve Tunus İnsan Hakları Ligi'nin konferanslarında aktif bir şekilde yer almıştır. Üçüncü olarak ise, MTI'nin öğrenci kanadı 15 bin öğrencinin imzasını alarak 18-20 Mayıs 1985'te toplanmış ve bu konferansta Tunus Genel Öğrenci Birliği (UGTE) kurulmuştur. UGTE'nin kuruluşu ile birlikte muhafazakârların Tunus Üniversitesi'ndeki hâkimiyeti kesinleşmiştir. ${ }^{48}$ MTI'nin ortaya koyduğu bu başarıya karşın, hükümet kendisini siyasi bir parti olarak tanımamakta 1srar etmiş ve hareketin üyelerini siyasetten dışlamıştır. Partinin Aralık 1986'da gerçekleştirilen konferansında kendisini iktidara taşıması beklenen üç aşamalı bir strateji uygulamaya karar verilmiştir. İlk aşama hareketin fikirlerini kamuoyuna tanıtmayı amaçlamaktadır. İkinci aşama ise İslami bir hükümet için gerekli olan alternatif İslami programlar oluşturulmasını öngörmektedir. Son aşamada ise, hükümet kurulacak ve zafere ulaşılacaktır. ${ }^{49} \mathrm{Bu}$ üç aşamalı strateji, MTI'nin siyasal alanda aktif bir şekilde mücadele etme konusundaki kararlılığını ortaya koymaktadır. Böylelikle, Burgiba görevinde kaldığı sürece siyasal alanda varlık gösterme imkanı olmayacağına inanan MTI üyeleri O’nun otoritesini sarsarak ülkenin siyasi liderliğini ele geçir-

\footnotetext{
47 David Seddon, "Winter of Disconte t: Economic Crisis in Tunisia and Morocco,"” MENP Reports, Vol. 14, No, 8, October 1984.

48 Hamdi, s. 49-50.

49 Hamdi, 52.
} 
me mücadelesine girişmiştir. ${ }^{50}$

Bu konferanstan birkaç ay sonra 9 Mart 1987'de izinsiz bir şekilde camide konuşma yapan Raşit Gannuşi tutuklanmıştır. Bunun üzerine yeniden sokak gösterileri başlamış ve yaşanan çatışmaların sonrasında kırk civarımda MTI üyesi tutuklanmıştır. Tunus'ta yaşanan bu olaylara paralel olarak, Fransa da aralarında Tunusluların bulunduğu ve İran ile bağlantılı olduğu iddia edilen bir grup teröristi tutuklamıştır. Fransa'nın adımını bir firsat olarak gören Tunus hükümeti ise MTI aleyhinde yürüttüğü kampanyayı daha da sertleştirmiş ve Gannuşi'nin izinsiz yaptığı konuşmanın bu olayla bağlantılı olduğunu iddia etmiştir. Dahası, MTI üyeleri hükümeti devirmeye çalışmak ve Humeyni yanlısı olmakla suçlanmıştır. ${ }^{51}$ Hükümetin sergilediği bu katı tutumdan rahatsız olan geniş kitleler üniversitelerde MTI yanlısı gösteriler düzenlediler. Olayları fazla büyümeden kontrol altına almak isteyen Burgiba rejimi iki ay içinde 3000 MTI üyesini tutuklayarak karşıllk vermiş̧ir. ${ }^{52}$

Hükümet ve MTI arasındaki gerilimin iyice arttığı bu dönemde yaşanan bir saldırı olayların gidişatını derinden etkilemiştir. 2 Ağustos 1987'de Sousse ve Monastr şehirlerinde Avrupalı turistlerin kaldığ 1 otellere yapılan bomba1 saldırılar üzerine Burgiba içişleri bakanına İslamcılar üzerindeki baskıyı arttırmasını ve olaylarla ilişkili olanların tutuklanması emrini vermiştir. ${ }^{53}$ Saldırıları gerçekleştirmekle suçlanan Behriz Boudagga'nın saldırı emrini MTI'nin üst düzey mensuplarından aldığını söylemesi ise hareketin kamuoyu önünde oldukça zor bir durumda kalmasına neden olmuştur. Bununla birlikte, hareket olayları kınamış ve şiddete başvurulmasının kabul edilemeyeceğini Paris'te dağıttığı üç ayrı bildiri ile ifade ederek bombalı saldırılarla herhangi bir ilişkisi bulunmadığını ortaya koymuştur. Ayrıca MTI gösteriler düzenleyerek, ulusal ve uluslararası basına açıklamalar yaparak Burgiba rejimini kendisine yönelik saldırıları karşısında kendisini savunmaya çalışmıştır. Buna karşın, saldırılardan bir kaç hafta sonra başlayan yargılamada önde gelen 60 MTI üyesi yabancı bir devletle işbirliği yaparak rejimi devirmekle ve isyan çıkarmakla suçlanmıştır. ${ }^{54}$

50 Micheal C. Dunn, "The Al-Nahda Movement in Tunisia: From Renaissance to Revolution", Islamism and Secularism in North Africa, John Reuedy(Der.), London, Macmillan, 1994, s. 149.

51 Boulby, s. 611.

52 Shahin, s. 97-98.

53 Ibid.

54 Hamdi, s. 53-56. 
Suçlamaların doğasına bakıldığında aslında Burgiba'nın "İslamcı tehdide" tam anlamıyla son vermeyi ve MTI üyeleri için ölüm cezasını istediğini göstermektedir. Ne var ki, Burgiba'nın bu isteği Fransa, Amerika, Suudi Arabistan ve Cezayir tarafından olumlu karşılanmamıştır. Benzer şekilde, içişleri bakanı Zeynelabidin Bin Ali de MTI üyelerinin ölüm cezası ile cezalandırılmasının onları birer kahraman yapacağını belirtmiş ve buna karşı çıkmıştır. Ölüm cezası konusunda Fransız basının da benzer bir tutum sergilemesi ve rejimin bundan kaçınması gerektiğini vurgulaması ise dikkat çekicidir. Esasen Le Monde gazetesi suçlananların şehit olmayı umut ettiğini ve eğer ölüm cezası verilirse rejimin bunlara en büyük firsatı vereceğini yazmaktayd1. ${ }^{55}$ Davanın sonunda açıklanan kararda yedi kişi ölüm cezasına çarptırılmış. Gannuşi ise ömür boyu hapis cezasına çarptırılmıştır (Abadi, 2013: 499). ${ }^{56} \mathrm{Bu}$ karardan kısa bir süre sonra, MTI karşısında daha katı bir tutuma sahip olan General Bin Ali'yi Raşit Sfar'ın yerine başbakan olarak atayan Burgiba MTI ile mücadelesine devam etme konusundaki kararlı olduğunu göstermiştir. Oysa Burgiba'nın attığı bu adım kendisi için sonun başlangıcını ifade etmektedir. Bin Ali MTI ile yaşanan krizi uzun süredir sağlık sorunları bulunan Burgiba'nın yerine yeni başkan olarak geçmek için büyük bir firsat olarak görmüştür.

\section{Sonuç: Burgiba Döneminin Sona Ermesi ve İslamcı Hareketin Rolü}

Bin Ali'nin Burgiba'yı devirmesine giden süreçte birçok olay etkili olmuştur. Burgiba'nın ardından kimin devlet başkanı olacağı uzun süredir merak edilen bir konuydu. Burgiba'nın MTI ile yaşadığı derin kriz Raşit Sfar'1 görevden alarak 2 Ekim 1987'de Bin Ali'yi başbakan olarak atamasına neden olmuştur. ${ }^{57}$ Burgiba için artık bu sürecin tersine dönmesi söz konusu değildi ve MTI ile mücadele için devletin tüm imkânlarını seferber etmeye kararlıydı. Oysa Bin Ali'nin çok daha farklı planları vardı ve başbakan olarak atandıktan sadece 36 gün sonra Burgiba'nın yerine geçmeyi başardı. 7 Kasım 1987'de General Bin Ali, Burgiba'nın ülkeyi yönetemeyeceğini, bu nedenle görevinden alındığını ve kendisinin Tunus'un yeni cumhurbaşka-

55 Le Monde, "Ils veulent devenir des héros", 16 Eylül 1987.

56 John Esposito, The Islamic Threat : Myth or Reality, New York, Oxford University Press, 1995, s. 155.

57 Abadi, s. 500-502. 
nı olduğunu kamuoyuna duyurmuştur. ${ }^{58}$ Böylece Bin Ali, İslami hareketi bastırmak amacıyla daha baskıcı ve daha otoriter bir yönetim ortaya koyan Burgiba'yı kansız bir darbe ile devirmiştir.

Geriye doğru dönüp bakıldığında, Burgiba döneminin sona ermesine neden olan olayların köklerini daha eskide aramak gerekir. Ulusal bağımsızlık hareketinin lideri olarak iktidarı ele geçiren Burgiba'nın sekülerleşme reformları İslam'ın hem kurumsal hem de toplumsal alanda baskı altına almıştır. Medeni Kanunu'nun kabulü, geleneksel eğitim veren medreselerin kapatılması, dine dayalı mahkemelerin kapatılması ve Kuzey Afrika'da önemli İslami eğitim merkezlerinden biri olan Zeytune Medresesi'nin kapatılması Burgiba'nın gerçekleştirmek istediği modernleşme ve Batılılaşma vizyonunu yansitmaktadır. Öte yandan, Ramazan orucu ve başörtüsünün hedef alması Burgiba'nın sadece kurumsal değil aynı zamanda kültürel ve zihinsel bir dönüşümü hedeflediğini ortaya koymaktadır. Kendi ülkesine ve kendi kültürüne yabancılaşan İslami hareketin kurucuları bu reformlara tepki olarak sohbet halkalarında bir araya gelmiş ve toplumun içinde bulunduğu bu yabancılaşmaya çözüm aramıştır. Batılılaşmanın sonucu olarak yaşanan kültürel ve toplumsal sorunlara ek olarak ekonomik alanda da Burgiba rejimi başarısız politikalar hayata geçirmiş ve rejime tepki duyan kitlelerin büyümesine neden olmuştur.

Bu bağlamda, Bin Salah'ın sosyalist programının başarısız olması üzerine, Burgiba rejiminin kültürel, dini, ekonomik ve sendikacı grupları temsil etme iddiası büyük ölçüde geçerliliğini kaybetmiştir. ${ }^{59}$ Uygulanan ekonomi politikasından rahatsız olan kesimler Tunus'ta rejim karşısında konumlanmaya başlamıştır. Ekonomik bunalımın İslami hareketin oluşumunda ve siyasallaşmasında büyük rol oynadığı görülmektedir. Ekonomide uygulanan liberalizm politikası ülkenin büyümesine katkı sağlamış olsa da, zenginler ve fakirler arasındaki uçurumun iyice açılmasına neden olmuştur. Devletin turizm, taşımacılık ve sanayi alanlarında özel sektöre yaptığı yatırım belli bir kesimin hızlı bir şekilde gelirlerinin artmasına neden olurken halkın di-

58 Emma Murphy, "Ten years on Ben Ali’s Tunisia”, Mediterranean Politics, Cilt 2, No 3, 1997, s. 117. Ayrica bkz. Gizachew Tiruneh, "Democratic development in Botswana and Tunisia: A comparative analysis", Journal of Contemporary African Studies, Cilt 22, No 1, 2004, s. 16; L. B. Ware, "Ben Ali's constitutional coup in Tunisia", The Middle East Journal, Cilt 42, No 4, 1988, s. 592.

59 Dirk Vandewalle, "From the New State to the New Era: T6.oward a Second Republic in Tunisia", Middle East Journal. Cilt 42, No 4, 1988, s. 606. 
ğer kısmının daha da fakirleştiği görülmektedir. Bu gelişmeler sonucunda UGTT'nin üye sayısının büyük ölçüde arttığını ve hükümete karşı gittikçe daha muhalif bir tutum içine girdiğini gözlemlemek mümkündür. İşçilerin yaşam koşullarının gitgide kötüleşmesinden rahatsız olan UGTT'nin beklentilerini karşılamayan hükümet ise ekonomik olarak sıkıntı içindeki toplumun tepkisi karşısında yalnızlaşmaya başlamıştır. Hükümet ve UGTT arasında artan gerilim "Kara Perşembe" olarak bilinen 26 Ocak 1978'de açık bir çatışma halini alan şiddet olaylarının yaşanmasına neden olmuştur. Ülke geneline yayılan isyanların müdahale ile bastırılması sonucunda birçok kişi hayatını kaybetmiştir.

Burgiba rejiminin modernleşme ve ilerleme ideallerinin toplumda yaşattığ 1 bu travma, İslami hareketin kurumsallaşmasında itici bir güç oluşturmuştur. 1970'li yıllar boyunca siyasi olmayan bir duruş sergileyen muhafazakâr Tunuslular zaman içinde siyasi bir söylem geliştirerek ayrı bir kurum bünyesinde rejimin politikalarından duydukları rahatsızlığı ifade etmeye başlamıştır. İslami Yöneliş Hareketi (MTI) olarak ortaya çıkan bu yapı, ekonomik krizin derinleştiği ülkede alternatif bir siyasi bakış sergilemiştir. İslami hareketin kurumsallaşma yönündeki ilk girişimi olan ve 1960'lı yılların başında kurulan "Davet ve İletişim Grubu" kayda değer bir başarı sağlayamamıştır. Üniversitelerde etkili olan solcularla mücadele etmesi için hükümetin desteğiyle kurulan Kuran'1 Koruma Derneği ise hareketin olgunlaşması açısından önemli bir dönüm noktasıdır. ${ }^{60}$ Ayrıca, derneğin yayın organı olan al-Marifa dergisinde Raşid Gannuşi ve Abdelfettah Moro'nun farklı bir siyasi yaklaşım ortaya koyan makaleleri hareketin benimsediği fikirlerin daha geniş kitlelerle buluşmasını sağlamıştır. 1981 yılında MTI'nin resmen kurulmasıyla birlikte yeni bir dönemece girildiği görülmektedir. Sendika faaliyetlerini destekleyen MTI'nin toplumsal eşitlik ve adalet konusunda rejime yönelik katı muhalif bir tutum içine girdiği söylenebilir. Siyasi bir parti olarak tanınma talebinde bulunan MTI'nin ortaya koyduğu muhalefetten rahatsız olan Burgiba rejiminin tepkisi ise oldukça sert olmuş ve hareketin önde gelen isimleri tutuklanmıştır. Her ne kadar 1984 yılında serbest kaldığında Gannuşi hareketi yeniden yapılandırmaya çalışsa da, bu kez Burgiba rejimi İslamcıları tamamen etkisiz hale getirmek için MTI üzerindeki baskılarını arttırmıştır. MTI ve Burgiba arasındaki derin siyasi krizi firsat bilen Bin Ali ise böylece kısa bir süre sonra iktidarı ele geçirmiştir.

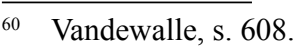




\section{Kaynakça}

Alaya Allani, The Islamists in Tunisia between confrontation and participation: 1980-2008. The Journal of North African Studies, Cilt 14, No 2, 2009, s. $257-272$.

Anne Wolf, "An Islamist 'renaissance'? Religion and politics in post-revolutionary Tunisia", The Journal of North African Studies, Cilt 18, No 4, 2013, s. 560-573.

Azzam Tamimi, Rachid Ghannouchi: A democrat within Islamism, New York, Oxford University Press, 2001.

Bruce Maddy-Weitzman, "The Islamic challenge in North Africa", B. Maddy-Weitzman ve E. Inbar (Ed.). Religious radicalism in the greater Middle East, London, Frank Cass, 1997, s. 171-188.

Charles A. Michaud, Tunisia: The Politics of Modernization, New York, F. A. Preager, 1964.

Clement H. Moore, Tunisia Since Independance: Dynamics of One-party Government. Berkeley, University of California Press, 1965.

David Seddon, "Winter of Disconte $\mathrm{t}$ : Economic Crisis in Tunisia and Morocco,"” MENP Reports, Vol. 14, No, 8, October 1984.

Derek Hopwood, Habib Bourguiba of Tunisia: The Tragedy of Longevity, Houndmills, Macmillan Press, 1992.

Dirk Vandewalle, "From the New State to the New Era: Toward a Second Republic in Tunisia", Middle East Journal. Cilt 42, No 4, 1988, s. 602-620.

Driss Abbassi, "La conception de l'histoire selon Bourguiba", Habib Bourguiba et l'établissement de l'Etat national 1957-1987: approches scientifiques du bourguibisme, Zaghouan, Publications F.T.R.S.I., 2000, s. 21-30.

Emma Murphy, “Ten years on Ben Ali’s Tunisia", Mediterranean Politics, Cilt 2, No 3, 1997, s. 114-122.

François Burgat, L'Islamisme au Maghreb: la voix du sud. Paris, Karthala, 1988.

Fred Halliday, "Tunisia's Uncertain Future" Middle East Report, 163, s. North Africa Faces the 1990's, 1990, s. 25-28. 
Gizachew Tiruneh, "Democratic development in Botswana and Tunisia: A comparative analysis", Journal of Contemporary African Studies, Cilt 22, No 1, 2004, s. 13-28.

Habib Bourguiba, Discours (1960-61). Vol. 8. Tunis, Secrétariat d'État à l'information, 1976.

Habib Boulares, Islam: The Fear and the Hope, London, Zed Books, 1990, Jacob Abadi, Tunisia since the Arab Conquest: The Saga of a Westernized Muslim State. Cornwall, Ithaca Press, 2013.

John Esposito, The Islamic Threat : Myth or Reality, New York, Oxford University Press, 1995.

John Esposito, ve J. Piscatori., "Democratization and Islam", The Middle East Journal, Cilt 45, No 3, 1991, s. 427-440.

John Esposito ve J. Voll, Makers of contemporary Islam, New York, Oxford University Press, 2001.

Kenneth J. Perkins, A History of Modern Tunisia, Cambridge, Cambridge University Press, 2014.

Stephen King, Liberalization Against Democracy: The Local Politics of Economic Reform in Tunisia, Bloomington, Indiana University Press, 2003.

Le Monde, "Ils veulent devenir des héros", 16 Eylül 1987.

Lisa Anderson, The state and social transformation in Tunisia and Libya: 1830-1980. Princeton, Princeton University Press, 1987.

L. B. Ware, "Ben Ali's constitutional coup in Tunisia", The Middle East Journal, Cilt 42, No 4, 1988, s. 587-601.

Marion Boulby, "The Islamic Challenge: Tunisia since Independence", Third World Quarterly, Cilt 10, No 2, 1988, s. 590-614.

Micheal C. Dunn, "The Al-Nahda Movement in Tunisia: From Renaissance to Revolution", Islamism and Secularism in North Africa, John Reuedy (Ed.), London, Macmillan, 1994, s. 149-165.

Micheal Willis, Politics and Power in The Maghreb: Algeria, Tunisia and 
Morocco from Independance to the Arab Spring. London: Hurst\&Co., 2012.

Michel Camau, Tunisie au present: une modernite au-dessus de tout soupçon? Paris, Editions du CNRS, 1987.

Mohamed Hamdi, The Politicization of Islam: A Case Study of Tunisia. Boulder, Colo: Westview Press, 1998.

Mohammed Sofi, "Modernization and Secularization in the Post-Independant Tunisia: An Analysis of Burguiba's reforms". Hamdard Islamicus. April-June, No 2. 2015, s. 7-38.

Mohsen Toumi, La Tunisie de Bourguiba à Ben Ali, Paris, Presses Universitaires de France, 1989.

Raşid Gannuşi, "Secularism in the Arab Maghreb", Islam and Secularism in the Middle East Azzam Tamimi ve John Esposito (Ed.), New York, NYU Press, 2000, s. 97-124.

Rory McCarthy, "Re-thinking secularism in post-independence Tunisia" The Journal of North African Studies, Cilt 9, No 5, 2014, s. 733-750.

Yadh B. Achour, "Politique et Religion en Tunisie". Confluences Méditerranée. 33, 2000, 95-106. 